\title{
Systematising Systemic Integration: 'War Refugees', Regime Relations, and a Proposal for a Cumulative Approach
}

\author{
Violeta Moreno-Lax*
}

\begin{abstract}
War and refugees are at the crossroads between IHL, human rights, and refugee law. Yet, the interplay between the three regimes remains unclear. This article offers a systematisation of available accounts, exposing their limits, and proposes an alternative, 'cumulative' approach to articulate their relationship. The final goal is to dispel persisting myths surrounding the fragmentation debate, contributing to the rationalisation of systemic integration. The proposal is grounded in Article 31 VCLT taken as a whole, as underpinned by the principle of good faith. A procedural rule of conduct and a redefinition of norm conflicts lie at the heart of this conceptualisation.
\end{abstract}

Keywords: war refugees, fragmentation, cross-fertilisation, systemic integration, lex specialis, norm conflict, autonomous concepts, Article 31(3)(c) VCLT, harmonisation

\section{Introduction: The Interplay between IHL, Human Rights, and Refugee Law}

Armed conflict has long been the theatre of the direst human rights violations and is the 'greatest cause of refugee flows today'. ${ }^{1}$ War is also at the crossroads between international humanitarian law (IHL), refugee law (IRL), and human rights law (IHRL). The 'triangulation' of these three regimes and their precise interrelation remain, however, unclear.

Discussion on the interplay respectively between IHL-IHRL, IHL-IRL, and IRL-IHRL is not new. ${ }^{2}$ Yet, it has attracted special attention following a series of pronouncements by the International Court of Justice (ICJ), ratifying the continued applicability of human rights in wartime. ${ }^{3}$ As a result, commentators agree that a shift in focus is required, from the question of whether to that of how human rights apply during armed conflict. ${ }^{4}$ A similar debate has emerged around the 'war flaw' and the purported inability of IRL to deal on its own with 'conflict-based' claims. ${ }^{5}$

\footnotetext{
* Lecturer in Law, Queen Mary, University of London [v.moreno-lax@qmul.ac.uk]. I am indebted to Magolsia Fitzmaurice and the journal reviewers for their suggestions on previous drafts.

${ }^{1}$ Speech by former UNHCR R. Lubbers 843 International Review of the Red Cross (IRRC) (2001) 578.

${ }^{2}$ See respectively O. Ben-Naftali (ed.), International Humanitarian Law and International Human Rights Law (OUP, 2011); D. Cantor and J.-F. Durieux (eds), Refuge from Inhumanity? War Refugees and International Humanitarian Law (Brill, 2014); and V. Chetail, 'Are Refugee Rights Human Rights?', in R. Rubio-Marín (ed.), Human Rights and Immigration (OUP, 2014) 19.

${ }^{3}$ Legality of the Threat or Use of Nuclear Weapons, Advisory Opinion, ICJ Reports (1996) 226; Legal Consequences of the Construction of a Wall in the Occupied Palestinian Territory, Advisory Opinion, ICJ Reports (2004) 136; Case Concerning Armed Activities on the Territory of the Congo (DRC v. Uganda), ICJ Reports (2005) 116.

${ }^{4}$ S. Sivakumaran, 'International Humanitarian Law', in D. Moeckli, S. Shah and S. Sivakumaran (eds), International Human Rights Law (2dn edn., OUP, 2014) 479, at 495.

${ }^{5}$ H. Storey, "Armed Conflict in Asylum Law: The "War-Flaw"' 31 Refugee Survey Quarterly (RSQ) (2012) 1; J.-F. Durieux, 'Of War, Flows, Laws and Flaws: A Reply to Hugo Storey' 31 RSQ (2012) 161; and S.S. Juss, 'Problematising the Protection of "War Refugees": A Rejoinder to Hugo Storey and Jean-Francois Durieux' 32 RSQ (2013) 122.
} 
Relying on the wider literature on fragmentation and systemic integration, the purpose of this article is twofold. It will, first, offer a systematisation of the different stances, proposing three models organised around the ideas of 'displacement', 'complementarity', and 'harmonisation'. ${ }^{6}$ The analysis will expose their limits, providing a comprehensive account of cross-systemic links in Sections 2 to 4. The shortcomings of available positions will then be addressed through a proposal to think of inter-regime relations holistically. The position taken by the European Court of Justice (ECJ) in the case of Diakité will be used as an example of the alternative 'cumulative' model proposed in Section 5 . $^{7}$

Overall, the final goal is to dispel persisting myths and assumptions surrounding the fragmentation debate, contributing to the rationalisation of the 'principle of systemic integration' ${ }^{8}$ The proposal is grounded in accepted canons of interpretation, taking the principle of good faith and the entirety of Article 31 of the Vienna Convention on the Law of Treaties (VCLT) as a starting place. ${ }^{9}$ Far from suggesting that there is a super-axiology overarching the whole of international law capable of organising normative values in hierarchical fashion, a procedural rule of conduct and a redefinition of norm conflicts lie at the heart of this systematisation. ${ }^{10}$

\section{Presuming Conflict? The Displacement Model}

The displacement model puts the emphasis on distinguishing factors and the exclusionary potential of the different law-sets bearing on war situations. Elements such as historical roots, the distinctive teloi of each regime, and their differing applicability thresholds are highlighted. ${ }^{11}$ In turn, these factors are put in a frame of conflict and a solution is attained by according pre-eminence to one or another regime or one or another norm, drawing on different acceptions of lex specialis, ${ }^{12}$ notwithstanding erratic jurisprudence and controversies surrounding the maxim. ${ }^{13}$

At least three variations of the model can be distinguished. First, 'systemic pre-eminence' relies on the thickest form of lex specialis, considering the entire branch of IHL as a 'self-contained regime' of leges speciales, limiting resort to IHRL or IRL as a fall-back recourse. Yet, possible lacunae are filled not with 'pure' IHRL/IRL standards, but as modified or adapted by IHL to the war context. 'Contextual pre-eminence', on the other hand, considers relations at norm, rather than

\footnotetext{
${ }^{6}$ Drawing partly on O.A. Hathaway et al., 'Which Law Governs during Armed Conflict? The Relationship between International Humanitarian Law and Human Rights Law' 96 Minnesota Law Review (2011-2012) 1883.

${ }^{7}$ Case C-285/12 Diakité, 30 January 2014.

${ }^{8}$ C. McLachlan, 'The Principle of Systemic Integration and Article 31(3)(c) of the Vienna Convention' 54 International and Comparative Law Quarterly (ICLQ) (2005) 279.

${ }^{9} 1155$ UNTS 331. On the customary law value of Arts 31 and 32, see Avena and other Mexican Nationals (Mexico v. USA), ICJ Reports (2004) 12, para. 83.

${ }^{10}$ It is not disputed that such meta-values exist, what is doubted is whether these are arranged in a specific hierarchy. See E. Voyiakis, 'International Law and the Objectivity of Value' 22 Leiden Journal of International Law (LJIL) (2009) 51.

${ }^{11}$ A. Eide, 'The Laws of War and Human Rights - Differences and Convergences', in C. Swinarski (ed.), Studies and Essays in Honour of Jean Pictet (ICRC/Martinus Nijhoff, 1984) 675.

${ }_{12}$ M. Koskenniemi (Rapp.), Study on Fragmentation of International Law: Difficulties Arising from the Diversification and Expansion of International Law, ILC 58 ${ }^{\text {th }}$ Sess., (A/CN.4/L.682), paras 46-222.

${ }^{13}$ See, generally, A. Lindroos, 'Addressing Norm Conflicts in a Fragmented Legal System: The Doctrine of Lex Specialis' 74 Nordic Journal International Law (2005) 27; N. Prud'homme, 'Lex Specialis: Oversimplifying a More Complex and Multifaceted Relationship?' 40 Israel Law Review (ILR) (2007) 355.
} 
regime, level, using lex specialis in individual cases to justify the exclusion of one rule in favour of another from another sub-system or to alter the substance of the rule concerned to adjust it to the exigencies of armed conflict. Finally, 'reverse displacement' constitutes the mirror image of 'systemic pre-eminence', with either IHRL or IRL being adopted as primary reference framework instead of IHL.

\subsection{Systemic Pre-eminence: Lex Specialis at Regime Level}

Until the 1970s, the predominant view was that IHL was the only applicable law in wartime. ${ }^{14}$ UNHCR similarly appeared to accept that persons fleeing armed conflict were not 'normally' refugees, ${ }^{15}$ supporting the understanding that a 'differential impact' had to be shown, based on 1951 Convention reasons, 'over and above the ordinary risks of ... warfare' for someone to qualify as such. ${ }^{16}$ Following the ICJ Nuclear Weapons Opinion, it is now accepted that 'the protection of [human rights] does not cease in times of war, except by operation of [derogation clauses]'. ${ }^{17}$ And UNHCR has also refined its position, clarifying that persons meeting the refugee definition qualify for 1951 Convention status, regardless of the cause of flight. ${ }^{18}$

Concerning the interaction between IHL and IHRL, the ICJ held that during wartime, the content of certain human rights must be interpreted in light of IHL. The Court observed that '[i]n principle, the right not arbitrarily to be deprived of one's life applies also in hostilities', but '[ $\mathrm{t}]$ he test of what is an arbitrary deprivation of life ... then falls to be determined by ... the law applicable in armed conflict'. ${ }^{19}$ This has led some scholars to maintain that IHL should prevail as a 'self-contained regime' or a set of leges speciales, displacing human rights en bloc. ${ }^{20} \mathrm{IHL}$, as the system specifically designed to regulate the conduct of hostilities, is taken to effectively set aside IHRL as the primary reference point to assess the legality of action. ${ }^{21}$

The reference to lex specialis was reiterated in the Wall Opinion, where the ICJ identified three possible scenarios concerning the relationship between IHL and IHRL. It concluded that there could be situations in which 'some rights may be exclusively matters of [IHL]; others may be exclusively matters of [IHRL]; yet others may be matters of both these branches'. When coming to the concrete situation at hand, the Court considered both these branches, but continued to emphasise IHL 'as lex specialis' ${ }^{22}$ On this basis, Hampson and Salama have suggested that the Court made "clear that lex specialis is not being used to displace human rights law. It is rather an indication that human rights bodies should interpret a human rights norm in

\footnotetext{
${ }^{14}$ See e.g. O. Ben-Naftali and Y. Shany, 'Living in Denial: The Application of Human Rights in the Occupied Territories' 37 ILR (2004) 8.

${ }^{15}$ UNHCR, Handbook on Procedures and Criteria for Determining Refugee Status (reissued December 2011), para. 164.

${ }_{16}^{16}$ Adan [1998] UKHL 15; [1999] 1 AC 293, at 311.

${ }^{17}$ Nuclear Weapons, para. 25.

${ }^{18}$ UNHCR, Summary Conclusions on International Protection of Persons Fleeing Armed Conflict and Situations of Violence (Cape Town Roundtable, December 2012).

${ }^{19}$ Nuclear Weapons, para. 25.

${ }^{20} \mathrm{Cf}$. B. Simma and D. Pulkowski, 'Of Planets and the Universe: Self-contained Regimes in International Law' 17 European Journal of International Law (EJIL) (2006) 483, at 492, rejecting the characterisation of international law branches as 'self-contained regimes'.

${ }^{21}$ M. Dennis, 'Non-Application of Civil and Political Rights Extraterritorially During Times of International Armed Conflict' 40 ILR (2007) 453.

${ }^{22}$ Wall Opinion, para. 106.
} 
the light of [IHL]'. ${ }^{23}$ But, as Hampson subsequently elaborated, this appears to imply that, where both IHL and IHRL are applicable, 'priority should be given to IHL' to guide the overall assessment. ${ }^{24}$

Few scholars have relied on the lex specialis tenet to describe the relationship between IHL and IRL in abstract terms, according pre-eminence to the former to adjudicate international protection claims in war situations. Hampson stands alone alerting to the 'danger' of IHL being contaminated by IRL in this context. ${ }^{25}$

\subsection{Contextual Pre-eminence: Lex specialis at Norm Level}

Instead of approaching the matter from the perspective of 'self-contained regimes', in line with the Wall observation that there 'may be exclusively matters of human rights law' even in wartime, ${ }^{26}$ other authors have identified situations in which IHRL should prevail, especially when IHL 'lack[s] greater specificity' or would only apply 'by way of analogy'. ${ }^{27}$ Rather than approaching the relationship between IHL and IHRL at regime level, lex specialis is used to administer individual norms relations, warranting a partial displacement of either IHL or IHRL, depending on the circumstances. This way, there is no allocation of pre-eminence of one system over the other by default. Primacy is established on a case-by-case basis. ${ }^{28}$

The 'special law' is perceived to be more effective than its general counterpart to regulate the situation at hand and to better reflect the will of the parties. ${ }^{29}$ Specificity, however, is volatile. It is considered contextual and dependent on perspective, predicated on event-related factors, including closeness to the battle field, or articulated in terms of other characteristics of the situation or the persons concerned, such as the definition of 'protected persons' in IHL, the category of 'everyone' in IHRL, or 'refugee' in the 1951 Convention. ${ }^{30}$ So, the outcome of the lex specialis operation cannot be determined beforehand.

Authors advocating this solution rely, in addition, on a broad construction of norm conflicts, as opposed to the classic, narrow understanding of traditional accounts. ${ }^{31}$ They include not only situations in which compliance with one rule constitutes a breach of the other, but also those in which diverging results may be achieved. ${ }^{32}$ Accordingly, 'apparent' conflicts, solvable via conform interpretation, are distinguished from 'genuine' ones, requiring formal methods of conflict resolution. ${ }^{33}$

\footnotetext{
${ }^{23}$ F. Hampson and I. Salama, Working Paper on the Relationship between Human Rights Law and International Humanitarian Law (E/CN.4/Sub.2/2005/14), para. 57.

${ }^{24}$ F. Hampson, 'The Relationship between International Humanitarian Law and Human Rights Law from the Perspective of a Human Rights Treaty Body' 90 IRRC (2008) 549, at 559.

${ }^{25}$ F. Hampson, 'The Scope of the Obligation Not to Return Fighters under the Law of Armed Conflict', in Cantor and Durieux (eds), supra note 2, 373, at 373.

${ }^{26}$ Wall Opinion, para. 106.

${ }^{27}$ H. Krieger, 'A Conflict of Norms: The Relationship between IHL and Human Rights Law in the ICRC Customary Law Study' (2006) 11 Journal of Conflict and Security Law (JC\&SL) 265, at 273.

${ }^{28}$ Hathaway et al. supra note 6, at 1902 ff; C. Droege, 'Elective Affinities? Human Rights and Humanitarian Law' 90 IRRC (2008) 501, at 522-524.

${ }^{29}$ ILC Study on Fragmentation, supra note 11, para. 60.

${ }^{30} 189$ UNTS 150.

${ }^{31}$ J. Mus, 'Conflicts between Treaties in International Law' 45 NILR (1998) 208; W. Jenks, 'The Conflict of Law-Making Treaties' 30 British Yearbook of International Law (BYIL) (1953) 401.

32 J. Pauwelyn, Conflict of Norms in Public International Law (CUP, 2003), at 184-188.

${ }^{33}$ Including jus cogens; Art. 103 of the UN Charter; conflict clauses in treaty law; or the operation of lex posterior in conformity with Art. 30 VCLT.
} 
Considering the difficulty of decoupling the general from the special and the fact that it cannot assign priority ex post, lex specialis is rejected as a tool to solve 'genuine conflicts' between rules from different regimes. Still, the maxim is accepted as an ex ante mechanism of 'conflict avoidance'. Following this technique, Milanović has taken the Nuclear Weapons Opinion as an example, recognising that the method may require one of the norms to be 'read down' to accommodate the other. This is 'the price to be paid for the joint application of IHL and IHRL'. 34

A similar stance has been advocated by Storey regarding IRL. The 'war-flaw' consists in the failure to acknowledge IHL as reference framework to analyse 'war refugee' claims. In his view, IHL should act as a supplement to the Refugee Convention in these cases, 'provid[ing] scope and content to its protective provisions', which may translate in the necessity to adapt the terms of the refugee definition to accommodate IHL. ${ }^{35}$ Consequently, where complementary forms of protection are envisaged, such as foreseen in the Qualification Directive, ${ }^{36}$ the IHL concepts of 'civilian' or 'armed conflict' should be taken into account to define their counterparts in EU law. ${ }^{37}$ Under this prism, for 'ready-made' definitions in IHL to be excluded, 'there would have to be reasons justifying the departure', outweighing the objectivity and transparency IHL infuses into the decision-making process. ${ }^{38}$

\subsection{Reverse Displacement}

'Reverse displacement' is the mirror image of the 'systemic pre-eminence' submodel. Although this position is not usually expressed in terms of lex specialis, adherents tend to promote the autonomy of the regimes concerned.

The European Court of Human Rights, through its exclusive reliance on IHRL to appraise violations perpetrated in war or occupation, champions this understanding. The Chechen cases exemplify the approach, with the Court applying the ECHR, ${ }^{39}$ not only without reference to IHL, but also in a manner inconsistent with it. ${ }^{40}$ Indeed, although it borrowed IHL terms, the Court did not employ them in an IHL sense. ${ }^{41}$

This is particularly visible in the proportionality assessment regarding the right to life - in sharp contradistinction to the Nuclear Weapons reasoning. Recourse to lethal force must be 'strictly proportionate' and justified by the 'permitted aims' listed in Article 2 ECHR. 'Automatic' resort to killing is excluded, regardless of any military advantage it may procure. ${ }^{43}$ There is an implicit duty of care stemming from the positive obligation on State Parties to 'secure to everyone within their jurisdiction the rights and freedoms defined in ... [the] Convention'. ${ }^{44}$ Accordingly, states have to

\footnotetext{
${ }^{34}$ M. Milanović, 'A Norm Conflict Perspective on the Relationship between International Humanitarian Law and Human Rights Law' 14 JC\&SL (2010) 459, at 461.

${ }^{35}$ Storey, supra note 5 , at 15.

${ }^{36}$ Directive 2011/95/EU [2011] OJ L 337/9 (QD).

${ }^{37}$ Along these lines, the UKAIT elaborated 'an IHL reading of Article 15(c) [QD]', which was subsequently reversed: $K H$ [2008] UKAIT 00023, paras 33-62; and $Q D \& A H$ [2009] EWCA Civ 620.

${ }^{38}$ Storey, supra note 5, at 15; and H. Storey, 'The "War Flaw" and Why it Matters', in Cantor and Durieux (eds), supra note 2, 39, at 40.

${ }^{39}$ (1950) CETS 5.

${ }^{40}$ W. Abresch, 'A Human Rights Law of International Armed Conflict: The European Court of Human Rights in Chechnya' 16 EJIL (2005) 741, at 742.

${ }^{41}$ Isayeva, Yusupova and Bazayeva v. Russia [2005] 41 EHRR 847, para. 175.

${ }^{42}$ Isayeva v. Russia [2005] 41 EHRR 791, para. 181.

${ }^{43}$ McCann v. UK [1995] 21 EHRR 97, para. 213.

${ }^{44}$ Art. 1 ECHR.
} 
plan law enforcement operations so as to minimize recourse to force and to conduct effective investigations of any incidents that may occur. ${ }^{45}$

By contrast, the notion of 'permitted aims' is unknown to IHL. IHL is neutral regarding the justness of war. ${ }^{46}$ Under IHL, if a combatant is killed, the proportionality assessment does not focus on the combatant himself, but on collateral damage and the effect on civilian persons and objects. ${ }^{47}$ If risks to civilians have been considered and the target is a legitimate military one, lethal force may be allowed even as first recourse. ${ }^{48}$

Although the Court appears to accept that, in case of an explicit derogation, a state of war would have been taken into account, ${ }^{49}$ there are no indications that the fundamentals of the proportionality analysis should be altered to accommodate IHL. To the contrary, the Court has asserted that 'obligation[s] under Article 2 continue to apply in difficult security conditions, including in a context of armed conflict' ${ }^{50}$ The same test is used in all instances of recourse to lethal force, probably because the same outcome could not be secured through an IHL-based reading. ${ }^{51}$

Following the Strasbourg Court, proponents of this approach reject the assumption that IHL and IHRL can or should be reconciled. ${ }^{52}$

Refugee scholars, in large part, have shown similar resistance to incorporating IHL into IRL analyses, invoking, if not hierarchical primacy in the formal sense, at least the prevalence of the 1951 Convention 'as a form of lex specialis' ${ }^{53}$ However, the degree of self-sufficiency attributed to IRL varies.

Some authors discard the overall 'utility' of IHL-based accounts, fearing the impact a substantive assimilation of IRL with IHL notions may entail. ${ }^{54}$ Others plead for autonomous constructions of common concepts particularly with regard to qualification criteria, despite the (implicit) reference in the 1951 Convention to 'the international instruments drawn up to make provision in respect of ... crimes [against peace, war crimes and crimes against humanity]' to determine exclusion from refugee status. ${ }^{55}$ The fact that refugeehood is not contingent on peace or war, the lack of consensus on the interpretation of key IHL terms, and differing membership in the relevant instruments justify the stance. ${ }^{56}$ This is the position adopted in Elgafaji, where the ECJ established that the interpretation of Article 15(c) QD had to be undertaken 'independently', with no consideration of IHL. ${ }^{57}$

\footnotetext{
${ }^{45}$ Khashiyev and Akayeva v. Russia [2005] 42 EHRR 20.

${ }^{46}$ M. Walzer, Just and Unjust Wars (4th edn., Basic Books, 1977), at 131-132.

${ }^{47}$ Arts 51(5)(b) and 52(2) AP I, 1125 UNTS 3.

${ }^{48}$ N. Lubell, 'Challenges in Applying Human Rights Law to Armed Conflict' 87 IRRC (2005) 737, at 744-749.

${ }^{49}$ See Isayeva, supra note 42, para. 191: 'the use of this kind of weapon ... outside wartime and without prior evacuation of the civilians, is impossible to reconcile with the degree of caution expected from a law enforcement body in a democratic society' (emphasis added).

${ }_{50}^{50}$ Al-Skeini v. UK [2011] 53 EHRR 18, para. 164.

51 Cf. A. Orakhelashvili, 'The Interaction between Human Rights and Humanitarian Law: Fragmentation, Conflict Parallelism, or Convergence?' 19 EJIL (2008) 161, at 174.

52 B. Bowring, 'Fragmentation, Lex Specialis and the Tensions in the Jurisprudence of the European Court of Human Rights' 14 JC\&SL (2010) 485, at 487.

53 J. McAdam, Complementary Protection in International Refugee Law (OUP, 2007), at 1 and 209.

${ }^{54}$ C. Bauloz, 'The (Mis)Use of International Humanitarian Law under Article 15(c) of the EU Qualification Directive', in Cantor and Durieux (eds), supra note 2, 245, at 269.

${ }^{55}$ Art. 1(F) Refugee Convention.

${ }^{56}$ G. Gilbert, 'Exclusion is Not Just about Saying "No": Taking Exclusion Seriously in Complex Conflicts', in Cantor and Durieux (eds), supra note 2, 155.

${ }^{57}$ Case C-465/07 Elgafaji [2009] ECR I-921, paras 45 and 39.
} 
While preserving a focus on IRL, other authors envisage a degree of openness to IHL, matching the evolution of UNHCR's approach. ${ }^{58}$ Durieux, albeit perceiving armed conflict as 'contextual' and refusing its characterisation as the 'subject matter' of a refugee enquiry, concedes to the permeability of IRL. ${ }^{59}$ Likewise, Woods has proposed that IHL be used as a set of 'indicia' in the context of expanded refugee definitions to establish refugee-producing events. ${ }^{60}$ The limits of a possible IHL contribution should thus be considered in light of IRL so that, for example, not all instances of armed conflict as defined in IHL may be relevant, if war has been declared but no actual fighting occurs or occupation is not met with armed opposition, ${ }^{61}$ as that could hardly justify a need for international protection. Conversely, meeting IAC/NIAC thresholds should not be determinative of an asylum claim, as there may be instances in which the effects of violence warrant the flight.

The difference between this structured or qualified permeability paradigm and the complementarity model discussed below is the point of departure. While the former situates IRL as the framework of reference, the latter places IRL and IHL on the same plane. Both recognise the possibility of synergies between the two regimes, but one views it from a cautious, rather than a positive, perspective.

\subsection{Displacement Assessment}

Overall, the major shortcoming of the displacement model is its 'all-ornothing' approach, either at systemic or contextual level, mediated by the lex specialis maxim and an over-expansive notion of normative conflict, which intertwines rules and exceptions from different normative orders, ultimately displacing or significantly altering the substance of the original norms. Lex specialis requires a material overlap, where both the specific and general provisions share 'the same substantive matter', ${ }^{6}$ presupposing the existence of a unified legislative will agreeing to the introduction of an implicit hierarchy between the norms concerned. The absence of these preconditions makes the notion volatile, rendering application beyond relationships within the same system unreliable. Consequently, under none of the three sub-models is there a win-win solution, whereby IHL, IHRL, and IRL coexist with the possibility of deploying their intended effects. Underlying all three variants, there is a lurking assumption that concurrent application comes at a cost.

\section{Pursuing Convergence? The Complementarity Model}

In practice, recourse to the lex specialis rule has been sparse and ambiguous. Different adjudication bodies have used it for different purposes. The ICJ, beside references in the Nuclear Weapons and Wall Opinions, has normally employed it to identify the law applicable to a dispute, especially in cases of overlap between customary and

\footnotetext{
${ }^{58}$ UNHCR, Safe at Last? Law and Practice in Selected EU Member States with Respect to AsylumSeekers Fleeing Indiscriminate Violence (July 2011), at 104, cautioning against IHL. Cf. UNHCR, Summary Conclusions on Complementarities between International Refugee Law, International Criminal Law and International Human Rights Law (Arusha Expert Meeting, April 2011); and Cape Town Roundtable, supra note 18.

${ }^{59}$ Durieux, supra note 5, at 164.

${ }^{60}$ T. Woods, 'The African War Refugee: Using IHL to Interpret the 1969 African Refugee Convention's Expanded Refugee Definition', in Cantor and Durieux (eds), supra note 2, 179.

${ }^{61}$ Common Art. 2, 75 UNTS 31, 85, 135 and 287.

${ }^{62}$ G. Fitzmaurice, 'The Law and Procedure of the international Court of Justice 1951-1954: Treaty Interpretation and Other Treaty Points' 33 BYIL (1957) 236, at 237.
} 
treaty rules on the same issue, or between general and local custom, highlighting the dispositive nature of international law. ${ }^{63}$ WTO authorities, in turn, have referred to the rule only with regard to strict cases of conflict within the WTO regime. ${ }^{64}$ By contrast, the Strasbourg Court has used it as a tool of procedural economy to select the most specific ECHR provision applicable in a given case. ${ }^{65}$ This partly explains why the maxim was not codified in the VCLT, ${ }^{66}$ and why it was abandoned in DRC $v$. Uganda, where the Court simply stated that both IHL and IHRL 'have to be taken into consideration' in wartime. ${ }^{67}$

As a result, some scholars have looked for synergies, highlighting the potential for mutual supportiveness and complementarity. In particular, the possibility of either system offering higher protection in any given case has been highlighted, speaking of the potential humanisation of IHL or the humanitarisation of IHRL. ${ }^{68}$ The accent is put on bridging clauses, such as the Martens clause in IHL, and derogation and 'saving clauses' in IHRL and IRL instruments, arguably allowing for a substantive 'merger' of the relevant standards. ${ }^{69}$

This is the direction taken by the Inter-American Commission on Human Rights. In Abella, it considered that, notwithstanding jurisdictional limits on its competence, Article 29 ACHR, precluding interpretations that would restrict rights recognised outside the Convention, ${ }^{70}$ enabled it to rely directly on the provision offering better protection to the individual, even '[i]f that higher standard is a rule of humanitarian law, ${ }^{71}$

The ICTY has followed suit. Regardless of jurisdictional constraints, the Tribunal has highlighted the similarity of IHL and IHRL. Both 'focus on respect for human values and the dignity of the human person', sharing 'a common "core" of fundamental standards ... from which no derogation is permitted', protecting individuals from the most 'heinous acts' at all times. ${ }^{72}$ This justifies substantive borrowing from IHRL 'to determine the content of customary international law in the field of humanitarian law, ${ }^{73}$ On the other hand, the Tribunal has been mindful to recall that the borrowing can only happen if IHRL notions 'take into consideration the specificities of [IHL],. ${ }^{74}$ On this basis, it has developed its own jurisprudential line on torture, taking guidance from IHRL, but keeping IHL features in mind. ${ }^{75}$

\footnotetext{
${ }^{63}$ See respectively Gabcikovo-Nagymaros Project case (Hungary v. Slovakia), ICJ Reports (1997) 7, para. 132; and Case Concerning Right of Passage over Indian Territory (Merits) (Portugal v. India), ICJ Reports (1960) 6, at 44.

${ }^{64}$ See e.g. Turkey - Restrictions on Imports of Textile and Clothing Products, WTO/DS34/R, 31 May 1999, para. 9.94.

${ }^{65}$ On Art. 6(1) as lex specialis of Art. 13 ECHR, see Brualla v. Spain, [2001] 33 EHRR 57, para. 41.

${ }^{66}$ Discussions focused instead on the lex posterior maxim, introduced in Art. 30 VCLT. See I. Sinclair, The Vienna Convention on the Law of Treaties (MUP, 1984), at 94.

${ }^{67}$ DRC v. Uganda, para. 216.

${ }^{68}$ See, respectively, T. Meron, 'The Humanization of Humanitarian Law' 94 AJIL (2000) 239; and J. d'Aspremont and J. de Hemptinne, Droit international humanitaire (Pedone, 2012).

${ }^{69}$ R. Arnold and N. Quenivet (eds), International Humanitarian and Human Rights Law: Towards a New Merger in International Law (Martinus Nijhoff, 2008).

${ }^{70} 1144$ UNTS 123.

${ }^{71}$ Abella v. Argentina, Case 11.137, Report No. 55/97, 18 November 1997, paras 164-165. Cf. IACtHR, rejecting direct application of IHL, but not precluding its interpretative potential in Las Palmeras v. Colombia (Preliminary Objections), Series C, Case No. 67, 4 February 2000, para. 33.

${ }^{72}$ Čelebići, IT-96-21-A, Appeals Chamber, 20 February 2001, para. 149.

${ }^{73}$ Kunarac, IT-96-23-T and IT-96-23/1-T, 22 February 2001, para. 467.

${ }^{74}$ Ibid., para. 471.

${ }^{75}$ R. Cryer, 'The Interplay of Human Rights and Humanitarian Law: The Approach of the ICTY' 14 JC\&SL (2010) 511.
} 
The Human Rights Committee has also asserted that 'both spheres of law are complementary, not mutually exclusive'. ${ }^{76}$ Adopting what has been denominated a 'belt and suspenders' approach, it has relied on both bodies of law as providing a continuum of protection. ${ }^{77}$ In the Committee's view, during armed conflict IHL rules become applicable 'and help, in addition to [the derogation clause] of the [ICCPR], to prevent the abuse of a State's emergency powers'. ${ }^{78}$ IHL provides a minimum floor of non-derogable rights complementing ICCPR protection during hostilities. ${ }^{79}$

The theory has been imported to the IRL-IHL terrain, to articulate the relationship between the 1951 Convention and the law of armed conflict. ${ }^{80}$ In wartime, the Refugee Convention allows for derogation in accordance with its Article 9. Therefore, IHL, considering its non-derogable/customary law character, gains particular relevance in such situation, acting as a 'brake' on the measures concerned. ${ }^{81}$ Although IHL instruments contain few special guarantees regarding a limited category of refugees, ${ }^{82}$ displaced individuals may still be treated as "protected persons', regardless of qualification under the 1951 Convention. ${ }^{83}$ And in the absence of derogation, refugees should benefit from the 'dual protection' of IRL applying 'concurrently' with IHL. ${ }^{84}$ Article 5, excluding an interpretation of the Refugee Convention impairing any rights granted elsewhere, supports this construction. ${ }^{85}$

The complementarity model assumes that IHL, IHRL, and IRL are engaged in a common mission, allowing their respective rules to be interpreted to avoid conflict. However, proponents of this method provide little details as for how the choice of law and the operation of integration should take place. Some rely on the prevailing factual circumstances, calling on pragmatics. ${ }^{86}$ They accept that there may be bounds to the humanisation of IHL considering the realities of war - thereby seemingly assuming $a$ priori notions of feasibility that prejudge the very case to adjudicate.

Borrowing from the lex specialis model, others emphasise the level of detail of the norms at play. They accord prevalence to the body containing the greater specificity, without questioning the (un-)suitability of ceding priority on grammatical grounds or semantic precision when dealing with norms from different regimes. ${ }^{87}$

Still others appeal to substantive considerations, evaluating the benefits and shortcomings of terminological bridges across disciplines. Fripp, accordingly, has

\footnotetext{
${ }^{76}$ HRC, General Comment No. 31 (CCPR/C/74/CRP.4/Rev.6), 21 April 2004, para. 11.

${ }^{77}$ W.A. Schabas, 'Lex Specialis? Belt and Suspenders? The Parallel Operation of Human Rights Law and the Law of Armed Conflict, and the Conundrum of Jus ad Bellum' 40 ILR (2007) 592, at 593.

${ }^{78}$ HRC, General Comment No. 29 (CCPR/C/21/Rev.1/Add.11), 24 July 2001, para. 3 ff. 79999 UNTS 171.

${ }^{80}$ W. Kälin, 'Flight in Times of War' 83 IRRC (2001) 629.

${ }^{81}$ D. Cantor, 'Laws of Unintended Consequence? Nationality, Allegiance and the Removal of Refugees during Wartime', in Cantor and Durieux (eds), supra note 2, 345, at 367.

${ }^{82}$ All provisions concern IACs only. See Art. 44 GC IV, on refugees who are nationals of a belligerent state; Art. 70 GC IV, on the relationship with the State of origin when it occupies the asylum state; Art. 73 AP I, on refugees who have had their status recognized before the start of hostilities; and Art. 45(4) GC IV, on non-refoulement.

${ }^{83}$ On this point and its limits, see V. Chetail, 'Armed Conflict and Forced Migration', in A. Clapham and P. Gaeta (eds), The Oxford Handbook of International aw in Armed Conflict (OUP, 2014) 700, at $707 \mathrm{ff}$.

${ }^{84}$ S. Jaquemet, 'The Cross-Fertilization of International Humanitarian Law and International Refugee Law' 83 IRRC (2001) 651, at 652.

${ }^{85}$ In this line, see F. Bugnion, 'Humanitarian Law and the Protection of Refugees' 24 RSQ (2005) 36.

${ }^{86}$ I. Scobbie, 'Principle or Pragmatics? The Relationship between Human Rights Law and the Law of Armed Conflict' 14 JC\&SL (2010) 449, at 456-457.

${ }^{87}$ Lubell, supra note 48, at 752; and Hathaway et al., supra note 6, proposing 'five factors for determining specificity', at $1917 \mathrm{ff}$.
} 
advocated a comprehensive understanding of 'persecution' and 'protection' informed by both IHRL and IHL standards. ${ }^{88}$ On this account, IHL helps pinpointing means and tactics of warfare 'contrary to the basic rules of human conduct' that may be regarded as persecution, broadening IRL/IHRL understandings. ${ }^{89}$ On the reverse, a teleological construction, drawing on IRL/IHRL, may expand the non-refoulement effect of IHL norms, offering a parallel route to international protection. ${ }^{90}$ The limits of substantive mergers are also assessed to avoid destructive alliances, maintaining, for instance, that the fact that 'combatants' cannot qualify as 'protected persons' under IHL should not directly translate into an automatic exclusion from refugee status without examination of Article 1F criteria. ${ }^{91}$ Prudence works the other way around as well, to escape restrictive imports from IRL. As a result, the concept of 'armed element', developed by UNHCR for operational purposes, should not influence the legal characterisation of 'combatant', restricting IHL protection of civilians. ${ }^{92}$ Usually, authors in this group look at protection levels by each set of rules, pleading for the higher standard in favour of the pro humanitatis principle. ${ }^{93}$

A final sector has suggested that focus on the minutiae of regime relations is a distraction. They propose, instead, a regime-transcendent paradigm, drawing on the IRL/IHL/IHRL intersection. ${ }^{94}$ Thus the notions of 'humanitarian non-refoulement' and 'temporary refuge' are considered as stemming directly from 'elementary considerations of humanity, ${ }^{95}$ shared as lex communis. ${ }^{96}$

Nonetheless, none of the variants of the complementarity approach fully expounds the particulars of regime interaction. Whether and to which extent IHL, IHRL or IRL should serve as interpretative aid or as main point of reference, on which basis, and how the choice should be made remains unexplained.

\section{Seeking Integration: A Systemic Approach to Harmonisation?}

A few commentators have attempted to theorise the interplay between IHL, IHRL, and IRL identifying a legal basis to articulate the link. The majority have resorted to

\footnotetext{
${ }^{88}$ E. Fripp, 'Inclusion of Refugees from Armed Conflict: Combatants and Ex-combatants', in Cantor and Durieux (eds), supra note 2, 128, at 130.

${ }^{89}$ Krotov [2004] EWCA Civ 69, para. 9, on punishment for draft evasion in the Chechen conflict, participation in which would have led the claimant to engage in IHL violations; BE (Iran) [2008] EWCA Civ 540, on landmine planting in civilian areas justifying allowance of an asylum claim; and $A M$ [2008] UKAIT 00091, para. 76, establishing that 'serious violations of peremptory norms of IHL and human rights' constitute persecution.

${ }^{90}$ R. Ziegler, "Non-Refoulement between "Common Article 1" and "Common Article 3"', in Cantor and Durieux (eds), supra note 2, 386.

${ }^{91}$ Fripp, supra note 88, at 140 ff. Cf. R. Brett and E. Lester, 'Refugee Law and International Humanitarian Law: Parallels, Lessons and Looking ahead' 83 IRRC (2001) 713, at 718.

${ }_{92}$ M. Janmyr, 'Revisiting the Civilian and Humanitarian Character of Refugee Camps', in Cantor and Durieux (eds), supra note 2, 225, at $233 \mathrm{ff}$.

${ }^{93}$ P.A. Fernández Sánchez, 'The Interplay Between International Humanitarian Law and Refugee Law' 1 Journal of International Humanitarian Legal Studies (2010) 329, at 380.

${ }^{94}$ G.S. Goodwin-Gill, 'Non-Refoulement, Temporary Refuge, and the "New" Asylum Seekers', in Cantor and Durieux (eds), supra note 2, 433.

${ }^{95}$ Corfu Channel Case (UK v. Albania), ICJ Reports (1949) 4, at 22. See also, Nicaragua, at 218, regarding Common Art. 3.

96 J. Moore, 'Protection against the Forced Return of War Refugees: An Interdisciplinary Consensus on Humanitarian Non-Refoulement', in Cantor and Durieux (eds), supra note 2, 411, at 412-413.
} 
Article 31(3)(c) VCLT to characterise the relationship in terms of conciliatory interpretation, striving to maintain the unity of international law. ${ }^{97}$

However, judicial practice offers little assistance in this respect. The ICJ recovered the hitherto dormant provision in Oil Platforms to justify interpretation of a bilateral treaty in light of customary law on the use of force, despite opposition by one of the parties and stark differences among individual judges. ${ }^{98}$ Article 31(3)(c) VCLT grounded the incorporation of a whole body of general law in the analysis of treaty norms. ${ }^{99}$ This contrasted with other uses of the clause by other courts, serving as an aid to interpretation to clarify ambiguous wording or to foster evolutive teleological constructions. ${ }^{100}$ The ICJ failed, nevertheless, to provide further guidance as to when and how Article 31(3)(c) VCLT should be applied.

This has not discouraged reliance on the 'principle of systemic integration' by several authors. Cassimatis, for instance, has advocated a method of interpretation that takes account of the core purposes and principles of each relevant regime in a manner that, at the same time, preserves the integrity of international law. ${ }^{101}$ The underlying assumption is the formal unity of the system and the duty to interpret individual rules on account of their 'normative environment' ${ }^{102}$ Holzer, from her part, has also based her inclusive construction of IRL in war settings on a systemic understanding of international law, positing that the 1951 Convention must be interpreted and applied 'in a way that is consistent' with IHL. ${ }^{103}$ This places the 'principle of harmonisation' at the centre of the interpretative strategy, according to which 'when several norms bear on a single issue they should ... be interpreted so as to give rise to a single set of compatible obligations'. ${ }^{104}$

Arguably, the ICJ has implicitly endorsed this understanding in DRC v. Uganda. The judgment uses language that is reminiscent of the wording of Article 31(3)(c) VCLT, when stipulating that 'Uganda at all times has responsibility for all actions and omissions of its own military forces in the territory of the DRC in breach of its obligations under the rules of [IHRL] and [IHL] which are relevant and applicable in the specific situation'. ${ }^{105}$

On this basis, some have ventured into the formulation of fixed criteria according to which the balancing of IHL and IHRL/IRL principles should be undertaken. Prud'homme has advanced a method that takes account of the type of conflict, the type of right, and the type of protected person to select the appropriate

\footnotetext{
${ }^{97}$ The discussion here is limited to 'systemic integration', leaving aside evolutive interpretation and inter-temporality. For analysis of the three notions, see S.T. Helmersen, 'Evolutive Treaty Interpretation: Legality, Semantics and Distinctions' 6 European Journal of Legal Studies (2013) 127.

${ }^{98}$ Case concerning Oil Platforms (Iran v. USA), ICJ Reports (2003) 161; and Separate Opinions of Judges Buergenthal, Simma, Higgins, and Kooijmans.

${ }^{99}$ See also Al-Adsani v. UK [2002] 34 EHRR 273, using the provision to pre-empt conflict between the right to fair trial and customary norms on State immunity.

${ }^{100}$ See respectively Mox Plant Case (Ireland v. UK) (Request for Provisional Measures Order) [2001] ITLOS List of Cases No. 10; US - Import Prohibition of Certain Shrimp and Shrimp Products, WT/DS58/AB/R, 12 October 1998; and Golder v. UK [1975] 1 EHRR 524.

101 A.E. Cassimatis, 'International Humanitarian Law, International Human Rights Law, and Fragmentation of International Law' $56 \operatorname{ICLQ}$ (2007) 623, at 631.

${ }_{102}$ Advisory Opinion on the Legal Consequences for States of the Continued Presence of South Africa in Namibia, ICJ Reports (1971) 16, at 31.

${ }^{103}$ V. Holzer, 'Persecution and the Nexus to a Convention Ground: Insights from Customary International Humanitarian Law', in Cantor and Durieux (eds), supra note 2, 101, at 108.

${ }^{104}$ ILC Report on the work of its $58^{\text {th }}$ Sess., UNGAOR 55 ${ }^{\text {th }}$ Sess., Suppl. 10 (A/56/10), 408.

${ }^{105}$ DRC v. Uganda, para. 180 (emphasis added).
} 
standard. ${ }^{106}$ However, she fails to reveal the legal grounding of this selection, why other factors should not be considered together with the chosen three, or how to proceed in case of conflict between the preferred criteria. Although Article 31(3)(c) VCLT may be taken to promote legal consistency, it is uncertain whether it goes as far as to predetermine the factors on which harmonisation should be structured.

At the other end of the spectrum, d'Aspremont suggests that the choice of reference framework is ultimately discretionary, only limited by mandate or jurisdictional constraints. As this is hardly a satisfactory solution from a legal certainty perspective, he advances that there may be pragmatic, extra-legal considerations pleading in favour of IHL, preventing the redundancy of the regime. ${ }^{107}$

Sands, in contrast, has rejected discretion as a basis to select the relevant framework, focusing instead on the peremptory language of Article 31(3)(c) VCLT. ${ }^{108}$ The provision explicitly reads that " $[\mathrm{t}]$ here shall be taken into account, together with the context ... any relevant rules of international law applicable in the relations between the parties'. So, the normative environment must be considered when interpreting IHL, IHRL, or IRL in armed conflict. But not all rules are important, only those that are 'relevant' and 'applicable'.

'Relevance' appears to relate to the subject matter of the norms at stake, ${ }^{109}$ whilst 'applicability' to the binding character upon the parties disputing their interpretation or possibly to general questions of scope. ${ }^{110}$ In turn, 'take into account' suggests consideration of the relevant rules to a lesser extent than 'apply', on the basis that norms in the background should not displace the norm being interpreted. However, the meaning of these terms is open to contestation. ${ }^{111}$

'Take into account' is arguably the key element. The travaux reveal that discussion on this point focused on the type of source. Negotiations advanced from general acceptance that interpretation should consider 'general principles of international law, ${ }^{112}$ to a more comprehensive position encompassing 'any rules of international law'. ${ }^{113}$ Yet, the bulk of the debate revolved around matters of intertemporal law. ${ }^{114}$

Although it remains difficult to discern what Article 31(3)(c) VCLT means, it should be clearer what it cannot imply. As a rule of interpretation, it should entail a norm of conduct, without prescribing a particular outcome beforehand. As such, it cannot lead to the modification of the object and purpose of the treaty under

\footnotetext{
${ }^{106}$ Prud'homme, supra note 13, at 391 (see from 386).

${ }^{107}$ J. d'Aspremont, 'Articulating International Human Rights and International Humanitarian Law: Conciliatory Interpretation under the Guise of Conflict of Norms-Resolution', in M. Fitzmaurice and P. Merkouris (eds), The Interpretation and Application of the European Convention on Human Rights (Martinus Nijhoff, 2013) 1, at 27-28.

${ }^{108}$ P. Sands, 'Treaty, Custom and the Cross-Fertilization of International Law' 1 Yale Human Rights and Development Law Journal (1998) 85, at 103.

109 EC and Certain Member States - Measures Affecting Trade in Large Civil Aircraft, WT/DS316/AB/R, 18 May 2011, para. 846.

${ }^{110}$ See respectively G. Marceau, 'WTO Settlement and Human Rights' 13 EJIL (2002) 753, at 781; and B. McGrady, 'Fragmentation of International Law or "Systemic Integration" of Treaty Regimes' 42 Journal of World Trade (2008) 589, at 612.

${ }^{111}$ See, generally, D. French, 'Treaty Interpretation and the Incorporation of Extraneous Legal Rules' $55 \operatorname{ICLQ}$ (2006) 281.

112 'De l'Interprétation des Traités', Annuaire de l'Institut de Droit International (Session de Grenade, 1956), at 330-332 and 337-338; and debate at the ILC, 765 ${ }^{\text {th }}$ sess., (A/CN.4/SR.765).

${ }^{113}$ See proposal by H. Waldock (Rapp.) and comments within the ILC, (A/CN.4/SR.769), in (1964) YBILC Vol. I, at 309-312.

${ }^{114}$ For details, see P. Merkouris, 'Debating the Ouroboros of International Law: The Drafting History of Article 31(3)(c)' 9 International Community Law Review (2007) 1.
} 
interpretation, reading into it additional or different obligations to the ones stipulated, deferring their content and effect to those of the 'relevant rules' in the background. ${ }^{115}$ That would amount to a wholesale incorporation of extraneous norms, replacing the substance of the treaty, in contravention of the good faith principle underpinning Article 31 VCLT as a whole. ${ }^{116}$

So, while it may be a sound starting point to consider that the parties to a treaty intended it 'to produce effects in accordance with existing law and not in violation of it', ${ }^{117}$ inferring thereby a positive intention to harmonise meanings and scopes with those of pre-existing norms, in the absence of tangible indications to that effect, goes too far. ${ }^{18}$ Such an approach would give more weight to pre-existing norms than to the current treaty, undermining the pacta sunt servanda rule and arbitrarily fixing meanings and stifling the very purpose of law-making by conventional agreement, beyond the requirements of jus cogens, third-party entitlements, and general principles of law. ${ }^{119}$

Article 31(3)(c) VCLT should indeed be taken as a rule of interpretation, rather than as a source of applicable law. ${ }^{120}$ When consistent interpretation is no longer a technique - a means to an end - but becomes an end in itself, it crosses the line between method and substance. Seeking systemic coherence may drive interpretation, but it cannot be its final goal. The normative ideal may translate into a procedural guideline to avoid conflict and enhance consistency within international law, but there is no obligation to achieve substantive unity as a result. ${ }^{121}$ There is no inter-regime meta-objective of normative assimilation. The opposite, brought to its logical extreme, may mean that the aim pursued by a given norm can only be realised to the extent it does not cause fragmentation of pre-existing standards.

The system, however, is wide enough to accommodate a diversity of values, ${ }^{122}$ which may or may not be reconciled through good faith interpretation. The risk of fragmentation should not be overrated. ${ }^{123}$ Discussion on this issue has been dominated by anxieties yet unverified. ${ }^{124}$ The mere fact of characterising the widening and deepening of international law as 'fragmentation' carries a load of negative connotations implying a false dichotomy - the binomial: harmony is good, divergence is bad. But divergence (or diversity) does not per se amount to conflict. Diversity rather responds to a need for nuance and sophistication, for particular solutions tailored to the specificities of different problems, drawing on different axiologies.

\footnotetext{
${ }^{115}$ A. Orakhelashvili, 'Restrictive Interpretation of Human Rights Treaties in the Recent Jurisprudence of the European Court of Human Rights' 14 EJIL (2003) 529, at 537.

${ }^{116}$ M. Virally, 'Good Faith in Public International Law' 77 American Journal of International Law (AJIL) (1983) 130.

117 Right of Passage, at 142.

${ }^{118}$ Cf. Amoco International Finance Corporation v. Iran [1987-II] 15 Iran-USCTR 189, para. 112.

${ }^{119}$ Cf. McLachlan, supra note 8, at 311.

${ }^{120}$ For a similar approach regarding Art. 21(3) ICC Statute, see R. Young, 'Internationally Recognized Human Rights Before the International Criminal Court' 60 ICLQ (2011) 189.

${ }^{121}$ In this line, see A. Clapham, 'Concluding Remarks: Three Tribes Engage on the Future of International Criminal Law' 9 Journal of International Criminal Justice (2011) 689.

${ }^{122}$ M. Craven, 'Unity, Diversity and the Fragmentation of International Law' 14 Finnish Yearbook of International Law (2003) 3.

${ }^{123}$ G. Hafner (Rapp.), The Risk ensuing from Fragmentation of International Law, UNGAOR $55^{\text {th }}$ Sess., Suppl. 10 (A/55/10), Annex 321. For a more balanced account, see B. Simma, 'Fragmentation in a Positive Light' 31 NYU Journal of International Law and Politics (1999) 845.

${ }^{124}$ M. Koskenniemi and P. Leino, 'Fragmentation of International Law? Postmodern Anxieties' 15 LJIL (2002) 553; A.-C. Martineau, 'The Rhetoric of Fragmentation: Fear and Faith in International Law' 22 LJIL (2009) 1 .
} 
Coming back to IHL/IHRL/IRL, although there may be instances of irreducible conflict, in most cases the three regimes will be applicable in tandem, if not cumulatively as discussed below. Still, in the event of concurrent application, Article 31(3)(c) VCLT does not resolve the issue of which of them should be elevated as main reference point. Article 31(3)(c) VCLT enters the scene once that decision has already been taken. It governs the relationship of one particular treaty with its external normative environment, linking it to the wider system of international law. But it does not regulate cross-regime relations as such. How the decision on the reference framework should be made is what the next section explores.

\section{Reconfiguring Regime Relations from a Holistic Perspective}

\subsection{Concurrent Application: Cumulative Approach}

If IHL, IHRL, and IRL are to preserve their specific ethos, unity shall not be reduced to uniformity. ${ }^{125}$ Pulkowski draws a distinction between 'logical' and 'axiological' coherence particularly relevant in this regard. ${ }^{126}$ While the former postulates the avoidance of 'conflicts' in the strict sense, the latter goes into substantive considerations, requiring also the prevention of 'divergences' - as if meta-values overarching international law were arranged in a specific order. If one accepts that the content of such super-axiology is malleable and recognise the law-making capacity of states as sovereigns, then one should equally admit the introduction of new values into the system via customary or conventional rule. Even recognising in the protection of human rights 'the ultimate purpose of all law', ${ }^{127}$ that alone may not translate into automatic priority vis-à-vis competing values. And even if it could, residual uncertainties would remain if all human rights ideals were rendered absolute and placed at the same level, begging for further hierarchisation among them. ${ }^{128}$

To accommodate diversity, it is more appropriate to adopt a narrow conception of conflict. A wide notion thereof risks curtailing the development of the very system it is intended to preserve - if originality or specialism is characterised as divergence, and divergence as conflict, and conflict, in turn, solved by reference to pre-existing law, there is very little space for new teloi to emerge. On the contrary, when conflict is understood as the impossibility of simultaneous fulfilment of two concurrent obligations, a wider scope for tailored responses remains available.

On this basis, differences between IHL, IHRL, and IRL should not be automatically characterised as a 'conflict' to resolve or a 'divergence' to avoid. As long as one regime does not command what the other forbids, diversity should be tolerated. Thus in armed conflict situations there is no need to choose a particular reference framework. Instead, all three regimes should be considered to apply cumulatively. The essential point is to identify the range of state obligations applicable in the particular context. Cases of real conflict will be rare. And in the

\footnotetext{
${ }^{125}$ On different notions of 'unity', as structural necessity, substantive requirement, or epistemological postulate of international law, see D. Pulkowski, The Law and Politics of International Regime Conflict (OUP, 2014), at $204 \mathrm{ff}$.

${ }^{126}$ Ibid., at 214-215.

${ }^{127}$ H. Lauterpacht, International Law: Collected Papers, Vol. 2 (CUP, 1975), at 47.

${ }^{128}$ See, generally, S. Gardbaum, 'Human Rights as International Constitutional Rights' 19 EJIL (2008) 749; I.D. Seiderman, Hierarchy in International Law: The Human Rights Dimension (Intersentia, 2001); and M.T. Kamminga and M. Scheinin (eds), The Impact of Human Rights Law on General International Law (OUP, 2009).
} 
event of diverging commands, the state concerned will have to comply with the most stringent standard. ${ }^{129}$

When IHL permits what IHRL or IRL proscribe, there is no actual conflict. Parties to IHRL or IRL instruments subscribe to individual rights obligations of their own free will, thereby limiting the amount of discretion allowed to them under IHL the same occurs in the reverse, where IHL offers higher protection. Sovereign powers must be exercised within the parameters of contracted commitments. ${ }^{130}$ Following the pacta sunt servanda principle, 'every treaty in force is binding upon the parties to it and must be performed by them in good faith'. ${ }^{131}$ States cannot select or unilaterally modify their obligations without incurring international responsibility. ${ }^{132}$ Once a State concludes a treaty it undertakes to exercise its prerogatives in conformity with it. ${ }^{133}$ International obligations are cumulative and states must comply with all of them at all times they are applicable. ${ }^{134}$

This is the path followed in practice by the ICJ in both the Wall Opinion and DRC v. Uganda, despite the rhetoric of lex specialis and systemic integration employed in each case. Materially, the Court cumulated IHL and IHRL obligations, without displacing or altering the substance of any of the applicable norms. This is also the approach adopted by the Strasbourg Court in Al-Jedda. Adjudicating on detention, it established that IHL contained a power to resort to indefinite internment without trial in particular circumstances, rather than an obligation to do so. Therefore, compliance with ECHR standards was not compromised. It could be secured simply by not interning the applicant in contravention of Article 5 ECHR. ${ }^{135}$

The case for accumulation is supported by saving clauses in IHRL/IRL instruments and by the Martens clause in IHL, promoting a 'higher standards' approach. Also the reference in Additional Protocol I to 'other applicable rules of international law relating to the protection of fundamental rights during international armed conflict' goes in this direction, ${ }^{136}$ with the acknowledgment, in Additional Protocol II, 'that international instruments relating to human rights offer a basic protection to the human person' reinforcing this conclusion. ${ }^{137}$

In the relation between IHRL and IRL, human rights bodies as well as UNHCR have long accepted the cumulative application of non-refoulement guarantees. The end result is the 'absolutisation' of Article 33 of the Refugee Convention. Indeed, while the exception contained in Article 33(2) contemplates instances in which refugees who pose a threat to the security of the asylum country may be returned to persecution, that possibility has been neutralised by the IHRL prohibition of torture, allowing for no restrictions. ${ }^{138}$ Following this understanding,

\footnotetext{
${ }^{129}$ The argument has been developed elsewhere. See V. Moreno-Lax, 'Seeking Asylum in the Mediterranean: Against a Fragmentary Reading of EU Member States' Obligations Accruing at Sea' 23 International Journal of Refugee Law (2011) 174.

${ }^{130}$ For an example of discretionary power allowed by an EU asylum instrument, but still limited and structured by it, see Joined Cases C-411/10 and C-493/10 NS \& ME, 21 December 2011, para. 66.

${ }^{131}$ Art. 26 VCLT (emphasis added).

${ }^{132}$ See, for instance, Art. 30(5) VCLT.

${ }^{133}$ Wimbledon, at 25.

${ }^{134}$ Brazil - Measures Affecting Desiccated Coconut, WT/DS22/AB/R, 21 February 1997, at 12-13, speaking of WTO treaties 'as a single undertaking'.

${ }^{135}$ Al-Jedda v. UK [2011] 53 EHRR 23, para. $107 \mathrm{ff}$.

${ }^{136}$ Arts 51(1), 72, and 75(8) AP I.

${ }^{137}$ Preambular para. 3 AP II, 1125 UNTS 609.

${ }^{138}$ See e.g. E. Lauterpacht and D. Bethlehem, 'The Scope and Content of the Principle of NonRefoulement: Opinion', in E. Feller, V. Türk and F. Nicholson (eds), Refugee Protection in International Law (CUP, 2003) 87.
} 
refugees in war should benefit not only from IHL protections against forcible transfer or deportation, to the extent they qualify as 'protected persons', ${ }^{139}$ but cumulatively also from refoulement prohibitions in IHRL and IRL.

\subsection{Non-concurrent Application: Return to Article 31 VCLT}

Accumulation articulates the interplay between IHL, IHRL and IRL when they apply concurrently, according to their specific thresholds. For IHL to enter the scene, this means there has to be an armed conflict in IHL terms. ${ }^{140}$ Outside wartime or occupation, and beyond the very parties to the conflict, IHL has no direct role to play. When dealing with the aftermath of hostilities, for third countries unrelated to the confrontation, IHL does not constitute an immediate source of applicable law. ${ }^{141}$ Therefore, the examination of asylum claims by refugees from war shall not be carried out against IHL as reference framework. In such situations, IRL and IHRL become (cumulatively) the leading standards, ${ }^{142}$ with IHL possibly influencing their interpretation, pursuant to Article 31 VCLT.

Different regions have adopted different solutions to cater for this category of persons. In Africa and Latin America, states have adopted a broad refugee definition as well as a broad understanding of armed conflict, covering all those who owing to 'generalised violence, foreign aggression, internal conflicts, massive violations of human rights' or 'events seriously disrupting public order' have had to flee. ${ }^{143}$

Europe, in contrast, has opted to complement the 1951 Convention, drawing on 'international obligations under human rights instruments' and the principle of non-refoulement. ${ }^{144}$ Consequently, foreigners who do not strictly qualify as refugees, 'but in respect of whom substantial grounds have been shown for believing that ... if returned ... would face a real risk of suffering serious harm' must be granted subsidiary protection. ${ }^{145}$

What constitutes 'serious harm' is defined in the Qualification Directive. There are three options: death penalty or execution; torture or equivalent treatment; or 'serious and individual threat to a civilian's life or person by reason of indiscriminate violence in situations of international or internal armed conflict'. ${ }^{146}$ The intricacy of this formulation has given rise to intense debate, particularly concerning the weight to be accorded to armed conflict as a cause of flight and whether IHL notions may be imported into the definition. ${ }^{147}$

The ECJ, following Strasbourg's lead, ${ }^{148}$ concluded in Diakité that the 'usual meaning in everyday language of "internal armed conflict"” shall be preferred,

\footnotetext{
${ }^{139}$ Arts 45(4) and 49(1) GC IV, in IACs; Art. 17 AP II, in NIACs.

${ }^{140}$ Tadić, IT-94-1-AR72, 2 October 1995, para. 67.

${ }^{141}$ Cf. Ziegler, supra note 90.

${ }^{142}$ Exemplifying this approach, see Joined Cases C-175/08 Abdulla [2010] ECR I-1493, paras 51-54.

${ }^{143}$ See respectively Art. 3, Cartagena Declaration on Refugees, adopted at 'Coloquio sobre la Protección Internacional de los Refugiados de América Central, México y Panamá', 19-22 November 1984; Art. 1(2), OAU Refugee Convention, 1001 UNTS 45.

${ }_{144}$ Recital 34 QD. See also Case C-604/12 HN, 8 May 2014, paras 31-33.

${ }^{145}$ Arts 2(f) and 18 QD.

${ }^{146}$ Art. 15(c) QD.

${ }^{147}$ For elaboration and further references, see V. Moreno-Lax, 'Of Autonomy, Autarky, Purposiveness and Fragmentation: The Relationship between EU Asylum Law and International Humanitarian Law', in Cantor and Durieux (eds), supra note 2, 295.

${ }^{148}$ Sufi \& Elmi v. UK [2012] 54 EHRR 9. See also L. Tsourdi, 'What Protection for Persons Fleeing Indiscriminate Violence? The Impact of the European Courts on the EU Subsidiary Protection Regime', in Cantor and Durieux (eds), supra note 2, 270.
} 
describing simply 'a situation in which a State's armed forces confront one or more armed groups or in which two or more armed groups confront each other'. Neither the 'assessment of the intensity of such confrontations' nor the 'level of organisation' of the parties involved were considered decisive. ${ }^{149}$

Although the Court did not mention Article 31(3)(c) VCLT explicitly, it reached its conclusion after having considered the possible impact of IHL norms as presumptive 'relevant rules of international law applicable in the relations between the parties'. The Court, first, noted the terminological distinctions patent on simple reading of IHL texts. 'International armed conflict' and 'armed conflict not of an international character', which are the terms employed in Common Article 3 and Article 1(1) AP II, are not identical to the phrase 'international or internal armed conflict' used in EU law. Applicability thresholds were also taken into account. The Court observed that IHL requires 'the existence of either type of conflict ... as a trigger for [application]'. This, in the Court's eyes, stemmed from the very object of IHL, which is to 'govern the conduct both of [IACs] and of [NIACs]'. In that context, IHL is designed to 'provide protection for civilian populations in a conflict zone by restricting the effects of war', but, unlike EU law, 'it does not ... provide for international protection to be granted to certain civilians who are outside both the conflict zone and the territory of the conflicting parties'. ${ }^{150}$

Consideration of these factors pushed the Court to conclude to the irrelevance of IHL as interpretative aid in the sense of Article 31(3)(c) VCLT. It underlined precisely that because IHL definitions 'are not designed to identify situations in which ... international protection would be necessary', it was not required for a conflict to be categorised as IAC/NIAC to qualify as such under the Directive. ${ }^{151}$

Having discarded IHL's input, what the Court did instead - again without express mention - was to rely on a reading of Article 15(c) from the perspective of Article 31 VCLT taken as a whole. It decided that 'since [the Qualification] Directive ... does not define "internal armed conflict", the meaning and scope of that phrase must ... be determined by considering its usual meaning in everyday language, while also taking into account the context in which it occurs and the purposes of the rules of which it is part'. ${ }^{152}$ Both textual and teleological considerations played a significant part in the Court's reasoning. Beside having regard to ' $\mathrm{t}]$ he usual meaning' of armed conflict, it also looked at the specific purpose of subsidiary protection as a mechanism to 'complement and add to the protection' of the 1951 Convention. ${ }^{153}$

The rest of the decision links the Court's conclusion to the other components of Article 15(c) and its previous case law on the level and intensity of violence. Therefore, the main point of Diakité, for our purposes, is the interpretative strategy employed, arriving at an autonomous construction of 'armed conflict', based on Article 31(1) VCLT.

The method is similar to that adopted in other authorities. Sufi \& Elmi used 'armed conflict' also in its plain meaning, to adjudicate the case of two applicants risking ill-treatment if removed to Somalia, without importing the IHL qualifications. The opposite could have pre-empted the application of the ECHR. It would have modified the threshold criterion in Article 1, pursuant to which ECHR rights must be secured by Contracting Parties 'to everyone within their jurisdiction', regardless of

\footnotetext{
${ }^{149}$ Diakité, paras 28, 32 and 34.

${ }^{150}$ Ibid., paras 20, 22 and 23 (emphasis added).

${ }^{151}$ Ibid., paras 23 and 35.

152 Ibid., para. 27 (emphasis added).

${ }^{153}$ Ibid., para. 33.
} 
whether there is a conflict - let alone, one meeting IHL criteria - in the country to which the person is envisaged to return. Armed conflict, in a non-refoulement evaluation, pertains to the factual background to assess to establish whether removal conforms to Convention standards. But it does not possess the special legal meaning ascribed to the term under IHL. Following Article 31(4) VCLT, the party invoking an IHL reading of ECHR standards must provide proof to that effect. ${ }^{154}$

This does not mean IHL plays no role in these situations. As part of the factual analysis to determine whether the level of violence in Mogadishu was of such intensity as to pose per se 'a real risk to the life or person of any civilian in the capital', the Court recognised a possible function for IHL. Factors such as the 'methods and tactics' employed, whether these 'increased the risk of civilian casualties' or were 'directly targeting civilians', etc were indicative of the kind of violence and the risks run in the event of expulsion. Yet, as mere indicators, the Court alerted they were not 'an exhaustive list to be applied in all cases'. ${ }^{155}$ There may, indeed, be situations of general risk of ill-treatment where armed conflict is not a factor but non-refoulment protection is nonetheless activated. ${ }^{156}$

The same terms may have different meanings, depending on the context and the object and purpose of the treaty where they are found. ${ }^{157}$ The fact that other branches of international law employ IHL-like vocabulary does not translate into its legal technical meaning being imported. As noted by the International Tribunal for the Law of the Sea, 'the application of international rules on interpretation ... to identical or similar provisions of different treaties may not yield the same results'. ${ }^{158}$ The temptation to transplant legal notions from one regime to another mechanically should be resisted. The emergence of 'autonomous' concepts is not always synonymous with isolationist accounts of international law, but a consequence of diversity and specialisation, taking the object and purpose of a treaty as well as the obligations it creates seriously and in good faith. ${ }^{159}$ Ultimately, what is advocated here is a reconceptualisation of regime relations along the lines of the pacta sunt servanda rule and Article 31 VCLT taken as a whole - putting Article 31(3)(c) VCLT against the entire 'general rule of interpretation'.

\section{Conclusion: Rationalising Systemic Coherence}

In some instances, 'coherence has to be sacrificed for some other good'. ${ }^{160}$ As the previous sections have attempted to elucidate, there is no need for the search of axiological uniformity to systematise regime relations. The principle of good faith and the general rule of interpretation enshrined in the VCLT provide appropriate tools to articulate them in a rational way.

The unity of international law is flexible enough to accommodate diversity the entire system is in fact predicated on the existence of law-making powers of states

\footnotetext{
${ }^{154}$ Conditions of Admission of a State to Membership in the United Nations (Advisory Opinion), ICJ Reports (1948) 57, at 63; Western Sahara (Advisory Opinion), ICJ Reports (1975) 12, para. 116.

${ }^{155}$ Sufi \& Elmi, para. 241.

${ }^{156}$ MSS v. Belgium and Greece, [2011] 53 EHRR 2; Hirsi v. Italy, [2012] 55 EHRR 21.

${ }^{157}$ On autonomous concepts, see G. Letsas, 'The Truth in Autonomous Concepts: How to Interpret the ECHR' 15 EJIL (2004) 279. For concrete examples, see Cryer on the ICTY, supra note 75, at 514-516; and US - Shrimp on 'exhaustible natural resources' within the WTO.

${ }^{158}$ Mox Plant, para. 52.

${ }^{159}$ H. Lauterpacht, 'Restrictive Interpretation and the Principle of Effectiveness in the Interpretation of Treaties' 26 BYIL (1949) 48.

${ }^{160}$ J. Raz, Ethics in the Public Domain (OUP, 1994), at 287.
} 
pursuing a variety of objectives following the evolution of time and the emergence of new needs and societal preoccupations. In the absence of an overarching mechanism establishing value priorities across branches of the system, value-related judgments to allocate pre-eminence ex post do not seem justified. Therefore, employing intraregime devices such as the lex specialis maxim to regulate cross-regime relations is inappropriate. As the 'displacement model' in Section 2 has demonstrated, it does not solve the problem - it rather displaces it to a different plane. Similarly, the 'complementarity model' so long as it remains based on axiological assumptions of value convergence and adaptation is unfitting, as Section 3 has shown.

Article 31(3)(c) VCLT, if understood as a procedural rule of conduct, offers a better perspective. However, as the analysis of the 'harmonisation model' has disclosed in Section 4, the provision is incapable of determining on its own the reference regime among parallel standards. Where harmonious integration reaches its limits, the cumulative application paradigm, proposed in Section 5, offers a principled response, revealing that there is no real choice to be made in cases of concurrent application. Good faith requires the simultaneous observance by states of all their international obligations applicable in a particular situation. The way of accommodating divergence is through compliance with the various relevant standards, stemming from the different regimes, at the same time.

IHL, IHRL and IRL should hence be capable of deploying their intended effects, in accordance with their respective object and purpose and 'other applicable rules of international law' possibly 'granting greater protection' to the individuals involved. ${ }^{161}$ In most instances, the three regimes will adjust constructively to one another, without the interpreter having to engage in exercises of uncritical assimilation or arbitrary selectivity of the relevant norms.

Cases of real conflict in the form of truly opposing obligations will be extremely rare. At that point, perhaps, some may have evolved into jus cogens, while others become obsolete, rendering the conflict solvable in this way. Genuinely irreducible conflicts will have no immediate solution through interpretation. Those occasions, however, should not be demonised as causes of fragmentation, but rather seized as opportunities to re-open debates on value choices to be revisited.

\footnotetext{
${ }^{161}$ Arts 72 and 75(8) AP I. See also preambular para. 3 AP II; Art. 53 ECHR; Art. 5(2) ICCPR; and Art. 5 Refugee Convention.
} 